\title{
EFFECT OF CUMULATIVE APPLICATION OF NITROGEN AND PGPR ON THE VARIOUS TRAITS OF BARLEY (Hordeum vulgare L.) UNDER DROUGHT STRESS CONDITIONS
}

\author{
Ehsan Rezaei ${ }^{1 *}$, Mir Reza Miri ${ }^{1}$, Hamid Reza Shamsaee ${ }^{1}$, Mohsen Hamidi ${ }^{1}$, \\ Babak Sepehri ${ }^{1}$, Farid Golzardi ${ }^{2}$
}

1. Department of Agronomy, Varamin-Pishva Branch, Islamic Azad University,Varamin, Iran

2. Seed and Plant Improvement Institute, Agricultural Research, Education and Extension Organization (AREEO), Karaj, Iran

Received - October 19, 2016; Revision - December 24, 2016; Accepted - June 17, 2017

Available Online - June 30, 2017

DOI: http://dx.doi.org/10.18006/2017.5(3).302.308

\section{ABSTRACT}

KEYWORDS

Drought stress

Nitrogen, PGPR

Grain yield and biological yield

This study was contducted to evaluate the effect of cumulative application of nitrogen and PGPR on various growth attributes of barley under drought stress condition. Study was conducted in factorial split plot design on the basis of randomized complete blocks design with 4 replications in 20112012 at the research farm of Islamic Azad University, Shahr-e-Rey Branch, Tehran, Iran. Three irrigation intervals viz 80, 130 and $180 \mathrm{~mm}$ and nitrogen levels i.e. 0 (not used), 75 and $150 \mathrm{~kg}$.ha ${ }^{-1}$ was used as main factor while PGPR containing pure strains of Azotobacter (strain12), Pseudomonas (strainp-169), Azospirillum (strain OF) in two levels (not used and used) was usedas a sub factor. Interaction of drought stress with nitrogen application was found significant on grain yield, biological yield and weight of 1000grain $(\mathrm{P}<0.01)$. Further maximum grain $\left(4296.17 \mathrm{kgha}^{-1}\right)$ and biological yield $\left(9292.25 \mathrm{~kg} \cdot \mathrm{ha}^{-1}\right)$ was reported from the treatment containing $150 \mathrm{~kg} \mathrm{~N} \mathrm{ha}^{-1}$ and $80 \mathrm{~mm}$ irrigation. In case of dual interaction, drought stress, nitrogen application and PGPR gave maximum grain yield $\left(3061.08 \mathrm{kgha}^{-1}\right)$ while $180 \mathrm{~mm}$ irrigation without PGPR treatment has the lowest grain yield (1161.25 $\left.\mathrm{kgha}^{-1}\right)$.
\end{abstract}

\footnotetext{
* Corresponding author

E-mail: rezaii.ehsan@gmail.com(Ehsan Rezaei)
}

Peer review under responsibility of Journal of Experimental Biology and Agricultural Sciences.

Production and Hosting by Horizon Publisher India [HPI] (http://www.horizonpublisherindia.in/).

All rights reserved.
All the article published by Journal of Experimental Biology and Agricultural Sciences is licensed under a Creative Commons Attribution-NonCommercial 4.0 International License Based on a work at www.jebas.org.

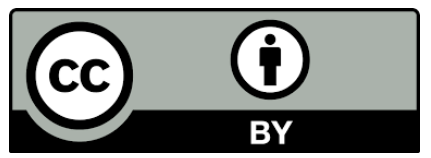




\section{Introduction}

Barley (Hordeum vulgare L.) is one of the major cereal in many dry areas of the world and due to its drought resistance, especially in late growing season which is concurrent with drought period, it is widely grown in arid and semi-arid areas (Golzardi et al., 2015). It's a strategic crop which is important for food and feed security (Bishaw, 2004). Drought stress at different growth stages is the primary restriction in the performance of these products. Further, moisture stress during grain filling and hastens leaf senescence, reduced the grain filling and mean weight of the grains (Austin, 1989). Similarly, Plaut et al. (2004) reported that reduction in the growth of wheat grain is depending on the degree of moisture stress and on the rate of stress development. Svobodová \& Míša (2004) reported that spring barley plants exposed to a water deficit at earlier growth stages (from emergence to the beginning of stem elongation) were able to compensate for the stress by the increase in a productive tiller number; while acute drought stressat stem elongation to anthesis stage was much worse and tillers withered away.

Nitrogen is one of the most important element and plays important role in the formation of various protein, enzymes, coenzymes, nucleic acids and cytochrome and also necessary component of chlorophyll (Shafe et al., 2011). According to Cossani et al. (2011) under rainfed conditions, nitrogen deficiency effect the grain yield. Demotes-mainard \&Jeuffroy (2004) showed that nitrogen deficiency during wheat growth period resulted in the loss of spike dry weight as well as grain number per spike. In a study Zaongo et al. (1997) studied the effect of different nitrogen rates on the sorghum yield and reported a direct relationship between $\mathrm{N}$ and 1000-grain weight. Further, Ryan et al. (2009) reported that higher nitrogen concentration increased the leaf area, tiller formation, LAI and LAD and this augmenting is led to much greater production of dry matter and grain yield. Similarly, Shaban (2013) suggested that for getting highest seed yield addition of nitrogen fertilizer is necessary. Intensive farming practices, that warrant high performance and quality, required extensive use of chemical fertilizers which are costly and also create environmental problems. Recently, there has been a resurgence of interest in ecofriendly, sustainable and organic agricultural practices (Esitken et al., 2005).

Plant growth promoting rhizobacteria (PGPR) are the soil bacteria inhabiting around/on the root surface and facilitate the plant growth (Wu et al., 2005). PGPR can be use as an alternative to mineral fertilizers and help in enhancing soil productivity and plant growth in sustainable agriculture. These PGPR not only increasing nutrient cycling, but also help in suppressing pathogens by producing antibiotics and fungal antagonistic substances. Khalid et al. (2004) reported that bacteria such as Pseudomonas, Azospirillum and Azotobacter have stimulatory effect on the plant growth. The inoculation of PGPR can reduced the famers dependency on the $\mathrm{N}$-fertilizers and also prevent the evacuation of soil organic matter which play an important role in decreasing environmental pollution up to a considerable extent (Kennedy et al., 2004).Yield can be analyzed in terms of different yield components, some of these have higher importance than others, this depending on the timing and intensity of stresses and their temporal development (Aggarwal \& Sinha, 1987). This study was formulated to find out the effect of cumulative application of nitrogen fertilization and PGPR on various growths attributes of barley under drought stress conditions.

\section{Materials and Methods}

Study was conducted in factorial split plot design on the basis of randomized complete blocks design with 4 replications in croping year 2011-2012 at the research station of Islamic Azad University, Shahr-e-Rey Branch, Tehran, Iran. In this experiment, three irrigation intervals viz. 80, 130 and $180 \mathrm{~mm}$ evaporation from class A evaporation pan and three nitrogen levels, 0 (not used), 75 and $150 \mathrm{~kg} \cdot \mathrm{ha}^{-1}$ were used as main factor and plant growth promoting rhizobacteria containing combination of Azotobacter(strain 12), Pseudomonas (strain p-169), Azospirillum (strain OF) at two levels viz 0-PGPR (not used) and PGPR-Inoculation (seed coating) was considered as a sub factor. Cell densities of PGPR per plote were $10^{7} \mathrm{CFU} / \mathrm{gm}$. Seeds were coated with gum Arabic as an adhesive and rolled into the suspension of bacteria until uniformly coated. Physicochemical property of pot soil was determine by standard methodology given by various researchers (Table 1). Among this total nitrogen $(\mathrm{N})$ was determined by using Kjeldahl method (Okalebo et al., 1993) while organic carbon (OC), available phosphorus $(\mathrm{P})$, potassium $(\mathrm{K})$, Iron $(\mathrm{Fe})$, Zinc $(\mathrm{Zn})$, Manganese $(\mathrm{Mn})$ and Copper $(\mathrm{Cu})$ was determined by the method given by Sparks et al. (1996).

Adequate plant protection measures and agronomic practices were made during the crop growth. Plot size was maintained $4 \times 2 \mathrm{~m}^{2}$ (row $\times$ row distance was $20 \mathrm{~cm}$ ), among this $50 \mathrm{~cm}$ space in either side of each row was left. Data were collected on the maturation of crop (150 days after sowing) and various growth attributes were recorded by standard methodology. Yield was calculated in terms of $\mathrm{kg} \cdot \mathrm{ha}^{-1}$ while harvesting index was calculated by below method given by Kozak \& Mądry (2006).

$$
\mathrm{HI}=(\text { Economical yield } / \text { Biological yield }) \times 100
$$

For measuring the number of grain spike $^{-1}, 30$ spikes treatment $^{-1}$ were randomly selected from each sub plot and it was followed by the counting number of grains spike ${ }^{-1}$ manually, this procedure was repeated for all the collected 30 spikes and average of this were used as number of grain spike ${ }^{-1}$. Number of spike in $\mathrm{m}^{2}$ was also recorded manually by counting the number of spike in one $\mathrm{m}^{2}$ in one meter area of the three central rows in each subplot and their mean was then calculated. For calculation of a thousand grain weight after harvesting, 8 samples of 100 seeds in each plots was randomly selected and then the average of a thousand grain weight was estimated by multiplying this average with 10 . Statistical 
analysis was performed using SAS 9.2 (SAS 2009) and EXCEL software and the means were compared using LSD test at 5\% probability level.

\section{RESULTS AND DISCUSSION}

\subsection{Effect on the weight of 1000 grain}

Analysis of variance with respect to weight of 1000-grain revealed that interaction of drought stress and nitrogen fertilizer, drought stress and PGPR was significant $(\mathrm{P}<0.01)$; but other interaction were not statistically significant (Table 2). Among various tested treatments, highest weight of 1000 -grain was achieved in dual interaction of drought stress and nitrogen fertilizer treatment while the lowest was reported from the untreated control. Treatment containing $80 \mathrm{~mm}$ irrigation and $150 \mathrm{~kg} \mathrm{~N} \mathrm{ha}^{-1}$ treatment has the higher $(42.80 \mathrm{~g})$ weight of 1000 grain while the treatment containing $180 \mathrm{~mm}$ irrigation without nitrogen has the lowest weight (26.35 g) of 1000 grain (Table 3). Further in case of treatment containing combined application of drought stress and PGPR, highest weight of 1000 grain weight (37.24 g) was reported from the treatment having $80 \mathrm{~mm}$ irrigation from evaporation pan and PGPR while treatment containing only 180 irrigation from evaporation pan without PGPR showed lowest weight (27.39 g) of 1000-grain (Table 4). According to Hatfield \& Prueger (2004) nitrogen increases the yield of wheat by increasing the number of spikes, grains per spike and weight of 1000-grain. In general, the yield components of wheat are directly affected by nitrogen. Further, Rao et al. (1991) suggested that drought stress at flowering stage can cause reduction in the weight of 1000-grains by reducing the transferring photo assimilates. In addition, these researchers also suggested that weight of 1000 grains also dependent of genetic structure of cultivar also (Rao et al., 1991).

\subsection{Effect on Grain Yield}

Result of study revealed a significant effect of PGPR and nitrogen fertilizer inoculation on the grain yield. According to the ANOVA, interactive effect of drought stress and nitrogen fertilizer and drought stress and PGPR on the grain yield in barley was significant at $1 \%$ probability level (Table 2). Results of study revealed that PGPR can reduce the harmful effects of stress.
Nitrogen plays an important role in plant metabolism. It facilitates the vegetative growth of plant by increasing the rate of photosynthesis. Mean comparison of the interactive effects of drought stress and nitrogen fertilizer showed that maximum grain yield belonged to the treatment with consumption of $150 \mathrm{~kg} \mathrm{~N} \mathrm{ha}^{-1}$ and irrigation $80 \mathrm{~mm}$ irrigation from evaporation pan (4296.17 $\mathrm{kg} \cdot \mathrm{ha}^{-1}$ ) while the lowest grain yield was reported from the treatment containing $180 \mathrm{~mm}$ from evaporation pan without $\mathrm{N}$ fertilizers (948.85 kg.ha-1) (Table 3). Also in case of dual interaction between drought stress and PGPR, maximum of Grain yield (3061.08 kg.ha ${ }^{-1}$ ) was reported from the treatment containing $80 \mathrm{~mm}$ irrigation along with PFPR while the treatment containing $180 \mathrm{~mm}$ irrigation without PGPR has lowest Grain yield (1161.25 kg.ha ${ }^{-1}$ ) (Table 4). These results are in agreement with findings of Zinselmeier et al.(1995), those who reported negative effect of drought stress on grain yield. Results of grain yield and yield components indicated that drought stress during the grain-filling period reduced grain yield by decreasing the number of fertile spikes and grains per plant. González et al. (1999) revealed that drought stress decreased grain yield by decreasing the number of grains per ear and grain weight. Cakmakci et al. (2007) also reported significant effect of PGPR on the plant growth and grain yield in barely plants. Similar types of significant increase in plant growth and final yield on the application of PGPR has been reported by Biswas et al. (2000) and Dobbelaere et al. (2003) in a separate experiments. Kloepper \& Beauchamp (1992) stated that plants such as rice, corn and sugar cane inoculated with bacteria had 10 to 30 percent higher yield than the un-inoculated treatments. Similarly, plant treated with PGPR increased dry matter accumulation in plant such as rice (Sudha et al., 1999) and barely (Cakmakci et al., 2007). Pervez et al. (2009) revealed that foliar and soil application of urea significantly increased number of grains spike $e^{-1}$, weight of 1000 grain and grain yield of crop. Mousavi et al. (2011) reported that nitrogen availability at the end of the season in some cases under the nitrogen limitation conditions increases the yield via increasing the grain size. This increase in grain weight is not much able to compensate for the reduction of the number of tillers or the number of grains per spike. Moselhy \& Zahran (2002) also reported significant effect of bio and mineral nitrogen fertilization on weight and number of grains spike $e^{-1}$ in barely plants.

Table 1. Physico-chemical properties of the study area soil.

\begin{tabular}{|c|c|c|c|c|c|c|c|c|c|c|c|c|c|c|}
\hline $\begin{array}{c}\text { depth } \\
\text { (cm) }\end{array}$ & $\begin{array}{l}\text { ds.m } \\
\text { (EC) }\end{array}$ & pH & $\underset{(\mathbf{p p m})}{\mathbf{P}}$ & $\underset{(\mathbf{p p m})}{\mathbf{K}}$ & $\begin{array}{c}\mathbf{N} \\
(\mathbf{p p m})\end{array}$ & $\begin{array}{c}\mathbf{O C} \\
(\%)\end{array}$ & $\underset{(\%)}{\text { CLAY }}$ & $\begin{array}{c}\text { SILT } \\
(\%)\end{array}$ & $\begin{array}{c}\text { SAND } \\
(\%)\end{array}$ & TEXTURE & $\begin{array}{c}\mathrm{Fe} \\
(\mathbf{p p m})\end{array}$ & $\begin{array}{c}\mathbf{Z n} \\
(\mathbf{p p m})\end{array}$ & $\underset{(\mathbf{p p m})}{\mathbf{M n}}$ & $\underset{(\mathbf{p p m})}{\mathbf{C u}}$ \\
\hline $0-30$ & 3.6 & 7.2 & 6.7 & 190 & 1.2 & 1.9 & 21 & 19.5 & 42 & $\begin{array}{l}\text { Sandy- } \\
\text { Clay }\end{array}$ & 1.5 & 2.4 & 2.5 & 2.5 \\
\hline
\end{tabular}


Table 2. Analysis of variance for various studied traits of barley

\begin{tabular}{|c|c|c|c|c|c|}
\hline \multirow[b]{2}{*}{ S.O.V. } & \multirow[b]{2}{*}{ d.f. } & \multicolumn{4}{|c|}{ Mean of Squares } \\
\hline & & 1000 grain weight & $\begin{array}{l}\text { Grain } \\
\text { yield }\end{array}$ & Biological yield & $\begin{array}{c}\text { Harvest } \\
\text { index }\end{array}$ \\
\hline Replication & 3 & 13.1038 & 2685.7029 & 15606.84 & 18.38117 \\
\hline Drought (D) & 2 & $266.706 * *$ & $212814.58 * *$ & $828467.826 * *$ & $416.71820 * *$ \\
\hline Nitrogen $(\mathbf{N})$ & 2 & $556.0015 * *$ & $162835.50 * *$ & $676399.077 * *$ & $64.61502 *$ \\
\hline $\mathbf{D} \times \mathbf{N}$ & 4 & $93.3530 * *$ & $43429.7073 * *$ & $161635.25 * *$ & $63.23841^{\mathrm{n} . \mathrm{s}}$ \\
\hline $\mathbf{E}\left({ }_{D \times N}\right)$ & 24 & 11.649956 & 2553.58 & 14955.153 & 27.22396 \\
\hline PGPR (P) & 1 & $152.8334^{\mathrm{n} . \mathrm{s}}$ & $12850.28^{*}$ & $39395.309^{*}$ & $116.61190^{*}$ \\
\hline $\mathbf{D} \times \mathbf{P}$ & 2 & $20.3718^{* *}$ & $514.0232 * *$ & $2318.902^{*}$ & $12.29553^{\text {n.s }}$ \\
\hline $\mathbf{N} \times \mathbf{P}$ & 2 & $5.23010^{\text {n.s }}$ & $2964.28^{\text {n.s }}$ & $14716.417^{\text {n.s }}$ & $18.47125^{\text {n.s }}$ \\
\hline $\mathbf{D} \times \mathbf{N} \times \mathbf{P}$ & 4 & $13.4622^{\text {n.s }}$ & $523.82^{\text {n.s }}$ & $2818.551^{\text {n.s }}$ & $13.46320^{\text {n.s }}$ \\
\hline $\mathbf{E}(\mathbf{P})$ & 27 & 11.8529 & 1005.658 & 5960.384 & 13.4911 \\
\hline Total & 71 & & & & \\
\hline C.V. & - & 10.83 & 15.78 & 15.57 & 9.82 \\
\hline
\end{tabular}

n.s. = Non-significant $*=$ Significant at $5 \%$ level $* *=$ significant at $\% 1$ level

Table 3. Effect of drought stress and nitrogen fertilizers interaction on various studied growth traits

\begin{tabular}{|c|c|c|c|c|c|}
\hline $\begin{array}{c}\text { Drought } \\
\text { stress }\end{array}$ & Nitrogen & $\begin{array}{l}1000 \text { grain } \\
\text { weight }(\mathrm{g})\end{array}$ & $\begin{array}{c}\text { Grain yield } \\
\left(\mathrm{kg} \cdot \mathrm{ha}^{-1}\right)\end{array}$ & $\begin{array}{c}\text { Biological } \\
\text { yield } \\
\left(\mathrm{kg}^{\left.-\mathrm{ha}^{-1}\right)}\right.\end{array}$ & $\begin{array}{c}\text { Harvest } \\
\text { index } \\
(\%)\end{array}$ \\
\hline \multirow{3}{*}{80 mm } & 0 kg.ha-1 & $29.88^{\mathrm{e}}$ & $1258.51^{\mathrm{e}}$ & $3418.86^{\mathrm{ef}}$ & $36.95^{\mathrm{cd}}$ \\
\hline & 75 kg.ha $^{-1}$ & $35.16^{\mathrm{c}}$ & $3281.75^{\mathrm{b}}$ & $7654.28^{\mathrm{b}}$ & $42.87^{b}$ \\
\hline & 150 kg.ha $^{-1}$ & $42.80^{\mathrm{a}}$ & $4296.17^{\mathrm{a}}$ & $9292.25^{\mathrm{a}}$ & $46.37^{\mathrm{a}}$ \\
\hline \multirow{3}{*}{$130 \mathrm{~mm}$} & 0 kg.ha ${ }^{-1}$ & $27.71^{\mathrm{g}}$ & $1045.82^{\mathrm{e}}$ & $2936.82^{\mathrm{ef}}$ & $3.59^{\mathrm{d}}$ \\
\hline & 75 kg.ha $^{-1}$ & $32.55^{\mathrm{d}}$ & $2402.77^{\mathrm{d}}$ & $6011.06^{\mathrm{d}}$ & $39.96^{\mathrm{bc}}$ \\
\hline & 150 kg.ha $^{-1}$ & $37.01^{\mathrm{b}}$ & $2907.53^{\mathrm{c}}$ & $678.01^{\mathrm{c}}$ & $42.82^{\mathrm{b}}$ \\
\hline \multirow{3}{*}{$180 \mathrm{~mm}$} & 0 kg.ha ${ }^{-1}$ & $26.35^{\mathrm{h}}$ & $948.85^{\mathrm{e}}$ & $2754.06^{\mathrm{f}}$ & $33.92^{\mathrm{e}}$ \\
\hline & 75 kg.ha $^{-1}$ & $28.86^{\mathrm{f}}$ & $1143.85^{\mathrm{e}}$ & $3377.57^{\text {ef }}$ & $34.43^{\mathrm{e}}$ \\
\hline & 150 kg.ha $^{-1}$ & $29.28^{\text {ef }}$ & $1250.63^{\mathrm{e}}$ & $3498.72^{\mathrm{e}}$ & $35.80^{\mathrm{d}}$ \\
\hline
\end{tabular}

Value given in table is mean of four replicates; Values followed by same letter did not differ significantly from LSD test at 5\% significance

Table 4. Effect of drought stress and PGPR Interaction on various studied growth traits

\begin{tabular}{|ccc|ccc|}
\hline Drought stress & PGPR & $\begin{array}{c}1000 \text { grain } \\
\text { weight }(\mathrm{g})\end{array}$ & $\begin{array}{c}\text { Grain yield } \\
\left(\mathrm{kg} \cdot \mathrm{ha}^{-1}\right)\end{array}$ & $\begin{array}{c}\text { Biological } \\
\text { yield }\left(\mathrm{kg} \cdot \mathrm{ha}^{-1}\right)\end{array}$ & $\begin{array}{c}\text { Harvest } \\
\text { index }(\%)\end{array}$ \\
\hline \multirow{2}{*}{$\mathbf{8 0} \mathbf{~ m m}$} & Not use & $34.65^{\mathrm{b}}$ & $2829.87^{\mathrm{b}}$ & $6627.76^{\mathrm{b}}$ & $41.38^{\mathrm{b}}$ \\
\cline { 2 - 6 } & used & $37.24^{\mathrm{a}}$ & $3061.08^{\mathrm{a}}$ & $6949.16^{\mathrm{a}}$ & $42.75^{\mathrm{a}}$ \\
\hline \multirow{2}{*}{$\mathbf{1 3 0} \mathbf{~ \mathbf { m }}$} & Not use & $31.33^{\mathrm{d}}$ & $2033.17^{\mathrm{cd}}$ & $5137.60^{\mathrm{d}}$ & $38.69^{\mathrm{d}}$ \\
\cline { 2 - 6 } & used & $33.52^{\mathrm{c}}$ & $2204.25^{\mathrm{c}}$ & $5351.66^{\mathrm{c}}$ & $40.23^{\mathrm{c}}$ \\
\hline \multirow{2}{*}{$\mathbf{1 8 0} \mathbf{~ m m}$} & Not use & $27.39^{\mathrm{f}}$ & $1067.64^{\mathrm{e}}$ & $3151.24^{\mathrm{f}}$ & $33.91^{\mathrm{f}}$ \\
\cline { 2 - 6 } & used & $28.94^{\mathrm{e}}$ & $1161.25^{\mathrm{e}}$ & $3269.00^{\mathrm{e}}$ & $35.52^{\mathrm{e}}$ \\
\hline
\end{tabular}

Value given in table is mean of four replicates; Values followed by same letter did not differ significantly from LSD test at 5\% significance 


\subsection{Effect on Biological yield (Biomass)}

Like weight of one thousand seeds and grain yield, biological yield was also affected by the drought stress and the negative effect of the drought condition can be decline by application of nitrogen fertilizers and PGPR. Analysis of variance suggested that biological yield also significantly influenced by the application of nitrogen fertilizer, PGPR at $1 \%$ significance level (Table 2). In dual interaction, combination of drought stress and nitrogen fertilizer have significant effect on plant growth and among various treatments combination, $80 \mathrm{~mm}$ irrigation from evaporation pan and use $150 \mathrm{~kg} \cdot \mathrm{ha}^{-1} \mathrm{~N}$ treatment has the higher $\left(9292.25 \mathrm{~kg} \mathrm{ha}^{-1}\right)$ biological yield while lowest biological yield $\left(2754.06 \mathrm{~kg} \cdot \mathrm{ha}^{-1}\right)$ was reported from the individual application of $180 \mathrm{~mm}$ evaporation pan (Table 3). Similarly, dual interaction of drought stress and PGPR was also proved effective in increasing biological yield (6949.16 kg.ha-1 ${ }^{-1}$. Here also180 mm irrigation from evaporation pan without PGPR has lowest biological yield $\left(3151.24 \mathrm{~kg} \cdot \mathrm{ha}^{-1}\right)$ (Table 4).These results are agreement with the findings of Anbessa \&Juskiw (2012), those who has conducted an experiment for finding out the effects of nitrogen on barley cultivars and concluded that biomass related trait was find higher on the application of $\mathrm{N}$ fertilizer. Nitrogen availability at the end of the season increases the barley yield by increasing the grain size (Mousavi et al., 2011). Further, Moser et al. (2006), reported negative effect of water stress on the biological yield. Also Stone et al. (2001) suggested that grain yield is strongly related to biological yield especially that accumulated after slicing. Canbolat et al. (2006) reported that inoculation of barley with PGPR strains increased shoot weight up to $40 \%$ compared with control.

\subsection{Effect on Harvest index}

Effect of nitrogen rate and PGPR on harvest index was significant at $5 \%$ level; but the effect of irrigation was significant at the $1 \%$ level (Table 2). Means comparison for the simple effect of irrigation revealed that the highest and lower Harvest Index percentage (42.07 and $34.72 \%$ ) was obtained under $80 \mathrm{~mm}$ irrigation and $180 \mathrm{~mm}$ irrigation from evaporation pan, respectively (Fig.1). Means comparison indicated that highest harvest index (41.67\%) was obtained under application of $150 \mathrm{~kg}$ $\mathrm{N} \mathrm{ha}^{-1}$ while it was reported $35.66 \%$ in control (Fig. 2). Inoculation of barley seeds with plant growth-promoting rhizobacteria caused significant differences in the Harvest index of barley. Means comparison of PGPR levels indicated that highest harvest index of barley $(39.50 \%)$ was obtained under inoculation PGPR than the un-inoculated PGPRcontrol (38\%)(Fig. 3). According to Bolaños \& Edmeads (1993) value of harvesting index may decrease with decreasing water availability. Water stress reduced the rate of photosynthesis by closing stomata, decreasing leaf area, stomata gravity and chloroplast and protoplast hydration, and protein and chlorophyll synthesis. However, reducing of photosyntate transport accumulates the products in leaves results in diminution in photosynthesis, limiting growth and crop yield (Hornok, 1992). Jayathilake et al. (2006) detected application of Azospirillum in combination with vermicompost and chemical fertilizers significantly maximum harvest index (67.3\%). Inoculation of seeds with Azotobacter and Azospirillum in the presence of chemical fertilizers resulted in improving both growth and yield of anise (Gomaa \& Abou-Aly, 2001). Lack et al. (2008) also reported that maize HI decreased under drought stress. Perhaps, in addition to decreasing produced dry matter, water deficit disrupts the partitioning of carbohydrates to grains and hence, decreases harvest index.

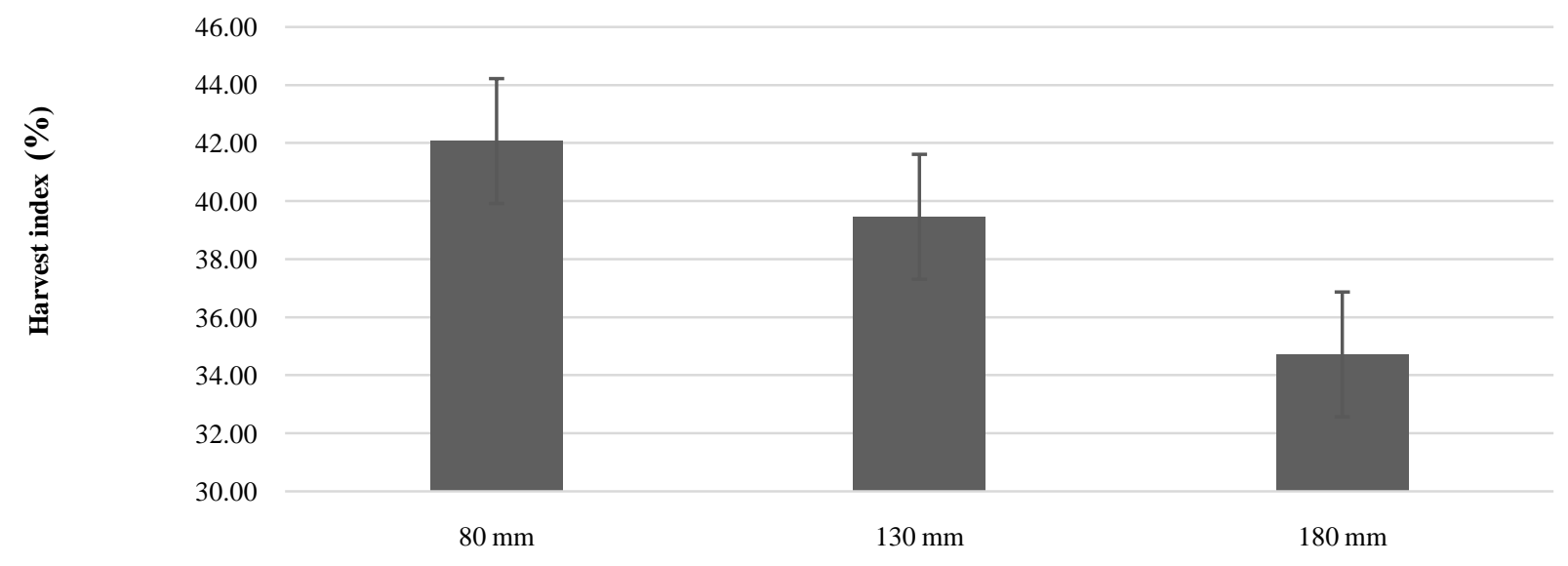

Drought stress

Fig. 1. Effect of drought stress on harvest index of barley 


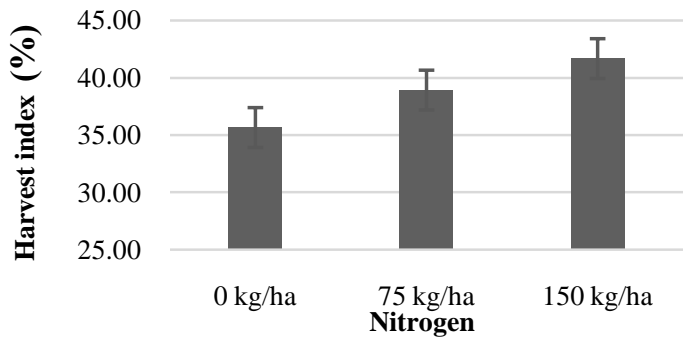

Fig. 2. Effect of nitrogen rate on harvest index of barley

\section{CONCLUSION}

Drought stress exertion at seed filling stage decreased yield and yield components of barley. Drought stress decreased amount of photosynthesis transfer to barley grains, there by it decreased yield and yield components. Also the result of study revealed that

\section{REFERENCES}

Aggarwal PK, Sinha SK (1987) Performance of wheat and triticale varieties in a variable soil-water environment. IV. Yield components and their association with grain yield. Field Crops Research 17: 45-53. DOI: http://dx.doi.org/10.1016/03784290(87)90081-5.

Anbessa Y, Juskiw P (2012) Nitrogen Fertilizer Rate and Cultivar Interaction Effects on Nitrogen Recovery, Utilization Efficiency, and Agronomic Performance of Spring Barley. ISRN Agronomy,

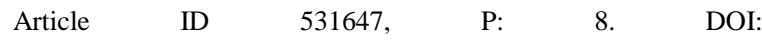
http://dx.doi.org/10.5402/2012/531647.

Austin RB (1989) Maximizing crop production in water-limited environments. In: Baker FWG (Ed.), Drought Resistance in Cereals. Published for ICSU Press by C.A.B. International, pp. 1325.

Bishaw Z (2004) Wheat and Barley Seed Systems in Ethiopia and Syria. Ph.D. Thesis, submitted to Wageningen University, Wageningen, Netherlands, Pp. 383.

Biswas JC, Ladha LK, Dazzo FB (2000) Rhizobia inoculation improves nutrient uptake and growth of lowland rice. Journal of Soil Science 64: 1644-1650. DOI: http://dx.doi.org/10.2136/sssaj2000.6451644x.

Bolaños J, Edmeades GO (1993) Eight cycles of selection for drought tolerance in lowland tropicalmaize. 1: Responses in grain yield, biomass, and radiation utilization. Field Crop Research 31: 233-252.DOI: http://dx.doi.org/10.1016/0378-4290(93)90064-T.

Cakmakci R, Donmez MF, Erdogan U (2007) The effect of plant growth promoting rhizobacteria on barley seedling growth, nutrient uptake, some soil properties and bacterial counts. Turkish Journal of Agriculture 31: 189-199.

Canbolat MY, Bilen S, Cakmakci R, Ahin S, Aydin F (2006) Effect of plant growth promoting bacteria and soil comaction on barley seedling growth, nutrient uptake,soil properties and rhizosphere microflora. Biology and Fertility of Soils 42:350-357. DOI: http://dx.doi.org/10.1007/s00374-005-0034-9.

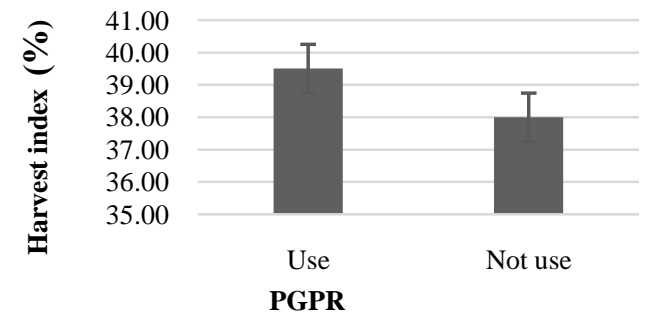

Fig. 3. The effect of PGPR on harvest index of barley

nitrogen fertilizer had maximum positive impact on yield and yield components of barely grain. In general, it can be conclude that entire growth characteristics were influenced by application of nitrogen fertilizers and PGPR

Cossani CM, Thabet C, Mellouli HJ, Slafer GA (2011) Improving wheat yields through $\mathrm{N}$ fertilization in Mediterranean Tunisia. Experimental Agriculture 47 : 459-475. DOI: http://dx.doi.org/10.1017/S0014479711000044.

Demotes-Mainard S, Jeuffroy MH (2004) Effects of nitrogen and radiation on dry matter and nitrogen accumulation in the spike of winter wheat. Field Crop Research 87: 221-233. DOI: http://dx.doi.org/10.1016/j.fcr.2003.11.014.

Dobbelaere S, Vanderleyden J, Yaacovokon Y(2003) Plant growth-promoting effects of diazotrophs in the rhizosphere. Critical Reviews in Plant 22: 107-149. DOI: http://dx.doi.org/10.1080/713610853.

Esitken A, Ercisli S, Karlidag H, Sahin F (2005) Potential use of plant growth promoting rhizobacteria (PGPR) in organic apricot production. Proceedings of the International Scientific Conference of Environmentally Friendly Fruit Growing, Pp. 90-97.

Golzardi F, Vaziritabar Y, Vaziritabar Y, SadatAsilan K, Ebadi SZ, Sarvaramini Sh, JafariSayadi MH (2015) Allelopathic effect of two Cynanchum acutum L. populations on emergence and shoot development of barley. Journal of Applied Environmental and Biological Sciences 5 : 166-175.

Gomaa A, Abou-Aly HE (2001) Efficiency of biofertilization in the presence of inorganic and organic fertilizers on growth, yield and chemical constituents of anise plant (Pimpinella anisum L.). Proceeding of 5th Horticulture Conference Ismailia, Pp. 73-80.

González A, Martín I, Ayerbe L (1999) Barely yield in water-stress conditions, the influence of precocity, osmotic adjustment and stomatal conductance. Field Crop Research 62: 23-34. DOI: http://dx.doi.org/10.1016/S0378-4290(99)00002-7.

Hatfield JL, Prueger JH (2004) Nitrogen Over-Use, Under-Use, and Efficiency. International Crop Science Congress Proceedings. 4th International Crop Science Congress, September 26 to October 1, 2004. Brisbane, Queensland, Australia. Pp. 52.

Hornok L (1992) Cultivation and processing of medicinal plants. Budapest, Academic Publication, Hungary. 
Jayathilake P, Reddy I, Srihari D, Reddy KR (2006) Productivity and soil fertility status as influenced by integrated use of n-fixing biofertilizers, organic manures and inorganic fertilizers in onion. Journal of Agricultural Science 2 : 46-58. DOI: http://dx.doi.org/10.4038/jas.v2i1.8112.

Kennedy IR, Choudhury AT, Kecskés ML (2004) Non-symbiotic bacterial diazotrophs in crop farming systems: can their potential for plant growth promotion be better exploited? Soil Biology and Biochemistry $\quad 36: \quad 1229-1244 . \quad$ DOI: http://dx.doi.org/10.1016/j.soilbio.2004.04.006.

Khalid A, Arshad M, Zahir ZA (2004) Screening plant growthpromoting rhizobacteria for improving growth and yield of wheat. Journal of Applied Microbiology 96: 473-480. DOI: http://dx.doi.org/10.1046/j.1365-2672.2003.02161.x.

Kloepper JW, Beauchamp CJ (1992) A review of issues related to measuring of plant roots by bacteria. Canadian Journal of Microbiology 38: 1219-1232. DOI: http://dx.doi.org/10.1139/m92202.

Kozak M, Madry W (2006) Note on yield component analysis. Cereal Research Communications 34: 933-940. DOI: http://dx.doi.org/10.1556/CRC.34.2006.2-3.222.

Lack S, Naderi A, Siadat SA, Ayenehband A, Nourmohammadi Gh, Moosavi SH (2008) The effects of different levels of irrigation, nitrogen and plant population on yield, yield components and dry matter remobilization of corn at climatical conditions of Khuzestan. Journal of Science and Technology of Agriculture and Natural Resources 42: 1-14.

Okalebo JR, Gathua KW,Woomer PL (1993) Laboratory methods of soil and plant analysis: a working manual, KARI, UNESCO, ROSTA, pp: 88.

Moselhy EI, Zahran MA (2002) Effect of bio and mineral nitrogen fertilization on barley crop grown on a sandy soil. The Egyptian Journal of Agricultural Research 3: 921-936.

Moser SB, Feil B, Jampatong S, Stamp P (2006) Effect of preanthesis drought nitrogen fertilizer rate and variety on grain yield, yield components and harvest index of tropical maize. Agricultural Water Management 81: 41-58. DOI: http://dx.doi.org/10.1016/j.agwat.2005.04.005.

Mousavi SK, Feizian M, Ahmadi A (2011) Evaluating the Effects of different methods of nitrogen fertilizer supply on the yield and yield components of wheat in irrigation conditions. Iranian Journal of Water and Soil $25: 19-28$.

Pervez K, Yousuf M, Imitas M, Islam M (2009) Response of wheat to foliar and soil application of urea at different growth stages. Pakistan Journal of Agronomy 41: 1197-1204.

Plaut Z, Butow BJ, Blumenthal CS, Wrigley CW (2004) Transport of dry matter into developing wheat kernels and its contribution to grain yield under post-anthesis water deficit and elevated temperature. Field Crops Research 86: 185-198. DOI:http://dx.doi.org/10.1016/j.fcr.2003.08.005.

Rao MS, Mendham NJ (1991) Soil-plant-water relations of oilseed raps (Brassica napus and B.compestris). The Journal of Agriculture Science 117:197-187.

Ryan J, Abdel Monem M, Amir A (2009) Nitrogen fertilizer response of some barley varieties in semi-arid conditions in Morocco. Journal of Agricultural Science and Technology 11: 227236.

Shaban M (2013) Biochemical aspects of protein changes in seed physiology and germination. International Journal of Advanced Biological and Biomedical Research $1: 885-898$.

Shafe L, Saffari M, Imam Y, Mohammadinejad G (2011) Effect of $\mathrm{N}$ and $\mathrm{Zn}$ fertilization on chlorophyll and leaf $\mathrm{N}$ content, yield and nutrients combination in grains of two corn (Zea mays L.) hybrids. Iranian Journal ofGrain and Plant Improvement 27 : 235-246.

Sparks DL, Helmke PA,Soltanpour PN (1996) Methods of soil analysis. Part 3, Chemical methods. (Eds.), Soil Science Society America, Inc. and America Soc. Agronomy, Inc., Wisconsin, pp: 1390.

Stone PJ, Wilson DR, Reid JB, Gillespie RN (2001) Water deficit effects on sweet corn. Water use, radiation use efficiency growth and yield. Australian Journal of Agricultural Research 52 : 103113. DOI: http://dx.doi.org/10.1071/AR99146.

Sudha SN, Jayakumar R, Sekar V(1999) Introduction and expression of the cry1Ac gene of Bacillus thuringiensis in a cerealassociated bacterium,Bacilluspolymyxa. Current Microbiology 38: 163-167. DOI: http://dx.doi.org/10.1007/PL00006781 .

Svobodová I, Míša P (2004) Effect of drought stress on the formation of yield elements in spring barley and the potential of stress expression reduction by foliar application of fertilizers and growth stimulator. Plant, Soil and Environment 10: 439-446.

Wu SC, Cao ZH, Cheung KC, Wong MH (2005) Effects of biofertilizer containing N-fixer, $\mathrm{P}$ and $\mathrm{K}$ solubilizers and $\mathrm{AM}$ fungi on maize growth: a greenhouse trial. Geoderma 125:155-166. DOI: http://dx.doi.org/10.1016/j.geoderma.2004.07.003.

Zaongo CGL, Wendt CW, Lascano RJ, Juo ASR (1997) Interactions of water, Mulch and nitrogen on sorghum in Niger. Plant and Soil 197 : 119-126. DOI: http://dx.doi.org/10.1023/A:1004244109990.

Zinselmeier C, Lauer MJ, Boyer JS(1995) Reversing droughtinduced losses in grain yield: sucrose Maintains embryo growth in maize. Crop Science 35: 1390-1400. DOI: http://dx.doi.org/10.2135/cropsci1995.0011183X003500050022x 